\title{
The Linguistic Behaviour of Characters in the Syrian TV Series Bab Al-Hara: A Case Study
}

\author{
Mohammed Al-Badawi ${ }^{1}$ \\ ${ }^{1}$ Department of English Language and Literature, Zarqa University, Zarqa, Jordan \\ Correspondence: Mohammed Al-Badawi, Department of English Language and Literature, Zarqa University, P.O. \\ Box: 132222, Zarqa, 13132 Jordan. Tel: 962-78-8191242. E-mail: badawi80_mohammad@yahoo.com
}

Received: September 10, 2013 Accepted: October 21, 2013 Online Published: November 24, 2013

doi:10.5539/ijel.v3n6p31 URL: http://dx.doi.org/10.5539/ijel.v3n6p31

\begin{abstract}
This study investigates the linguistic behaviour of the character Abu Jawdat, the chief police officer, with minor characters such as Abu Satoor and Subhi, and the major character of Muataz, in the fifth season of the Syrian TV series, Bab Al-Hara. In particular, it studies the linguistic behaviour of the above mentioned characters in light of (im)politeness theories, specifically Brown and Levinson's (1987) model of politeness and Culpeper's (1996) framework of impoliteness as well as Grice's (1975) cooperative principles and its maxims. The data of the study was transcribed in situations of police interrogations conducted by Abu Jawdat with Abu Satoor, Subhi and Muataz. The analysis of the selected chunks of conversation revealed that the change in the interactive linguistic behaviour of the characters can be explained by means of (im)politeness theories. Normally characters that possess power will get hold of the conversational floor and will have more chances to attack face.
\end{abstract}

Keywords: linguistic behaviour, positive face, negative face, pragmalinguistic analysis, face threatening acts, media discourse

\section{Introduction}

A great deal of work has been done in linguistics to show how speakers can be polite to one another in what they do and say. Politeness studies have also looked at how speakers mitigate impolite behaviour linguistically in order to maintain social cohesion. A good example of such mitigation might happen if a speaker says "I am sorry" to another person when they accidently bump into them in a bus station. A number of studies have also dealt with linguistic politeness in literary discourse (Leech, 1992; Short, Simpson, 1989; Benison, 1998; Abdesslem, 2001; Sharyan, 2000). Politeness is seen as useful in the study of drama, because, generally speaking, through politeness we express our strategic manipulation of language and how we achieve our goals in conversation, saying what is socially appropriate. Thus, it is assumed that the (im)politeness framework which brings the concept of face, that is defined as 'an emotionally sensitized concept about the self' (Culpeper, 1998), and the social variables of power, sex, social distance and relate them to motivated linguistic strategies in dramatic discourse will be helpful in understanding first, how characters might place themselves in relation to other characters. Second, how they manipulate others in pursuit of their goals, and third how the plot develops. This framework will give the chance to systematically describe how a character might gain favour of themselves with another in the text, or how a character may cause offense to another.

A possible obstacle here is that politeness theories have dealt with how people use politeness strategies to maintain harmony. While, in the case of dramatic discourse, the main dramatic events occur at instances of interactional conflict. Thus, in this paper we use both frameworks (politeness and impoliteness) to account for the linguistic behaviour of some characters in the Syrian Arabic drama, Bab Al-Hara.

\section{From Politeness to Impoliteness}

By the norms that Brown and Levinson (1987) use, politeness is explained in terms of face. In the common social sense of the word, face is equated with notions such as self-esteem, prestige and reputation. For the purpose of their study, Brown and Levinson (1987) classify face into two socio-psychological wants. The first is called positive face which refers to the want to be approved of. For instance, you may want me to agree with your ideas and opinions, admire you and your thinking, and acknowledge your existence. The second want is called negative face which expresses the want to be unimpeded, i.e., I assume you may want me to let you do 
and think whatever you want without me interfering with your verbal and non-verbal actions. However, in everyday life situations, our actions generally cause the other person's face to be threatened. If someone requests to borrow your car, you would consider this as an imposition on your social wants, and consequently this would be considered a Face Threatening Act (FTA). Normally FTAs are assessed based on a number of factors such as; the relationship between participants, and the size of the imposition involved in the performed act. For example, if I have been working for a long time in the lab on my research project, and I am starving for a snack, it would be easier to ask a long-standing colleague than a new one. This is because of the close social distance between me and my colleague. If my boss happened to be in the room, it would be more difficult to ask him than my new colleague because the power that my boss has over me is different from the power both my colleagues hold, which is equal to me. If I visit my colleague after work at their home, it would be less face threatening to ask for a cup of coffee instead of a meal, even though in some cultures it is the responsibility of the host to show their hospitability without asking their guests. This is a sign of appreciating their positive face. Brown \& Levinson (1987) claim that FTAs can also be ranked according to their size of imposition.

Linguistic politeness comes when one shows concern to support someone else's face. For instance, if I ask someone to give me a lift, my request would be perceived as an FTA towards that person's negative face because of the imposition and inconvenience caused by the request. So, instead of saying 'give me a lift!' it would be more polite to say 'Would you mind giving me a lift on your way? I live in your area.' On the surface of this polite utterance, I ask a question that gives my hearer the freedom to refuse instead of making a direct request as in the earlier example. By uttering an indirect polite request the speaker stands a better chance of being given a lift. In other words, by showing concern not to impose, I try to maintain social harmony with my colleague.

Another type of politeness strategies Brown \& Levinson (1987) use are the off-record strategies where the speaker will be indirect by leaving some space for addressee interpretation. For example:

- Give hints (violating relevance maxim): "It's cold in here."

- Understate (violating quantity maxim): A: Do you like my haircut? B: "It’s ok!"

- Be sarcastic or joking (violate quality maxim): "Yeah, he's a real rocket scientist!"

Before proceeding with impoliteness below, it is important to touch upon Grice's cooperative principle and its importance in the study of conversation. Grice (1975) claims that in order for a person to understand what is said, a Cooperative Principle must be assumed between the interlocutors. He argues that there is a group of principles that lead us to reach a particular interpretation of what is being said, unless there is an indication to the contrary. Grice theorizes that in order for the cooperative principle to be operative, a speaker should try to make their conversational contribution as is required at the stage at which it occurs by the accepted purpose or direction. (Grice 1975, p. 45)

The cooperative principle is based on the following four sub principles or maxims:

1. The maxim of quality which states that people say what they believe to be true.

2. The maxim of quantity which states that people be brief and informative when they make their conversational contribution.

3. The maxim of relation which states that people should only say what is relevant to the interaction.

4. The maxim of manner which states that people should be clear and try to avoid ambiguity or obscurity in their conversational contribution.

\section{Example:}
A: Hi, what would you like?
B: Four pints of skimmed milk, thanks.

In the above example, the interlocutors observed the cooperative principle maxims. They made their conversational contribution such as required at the appropriate stage of interaction which is supposedly a supermarket. They observed the purpose and the direction of the conversation. They were true, brief, relevant and unambiguous.

However, conversation is not always as ideal as this. On some occasions the interlocutor cannot be brief and true. This leads to 'flouting' the conversational maxims. Sometimes speakers flout the conversational maxims and intend their hearer to be aware of this. For example, in the situation below the person serving the customer suggests that the customer is flouting the maxim of quantity saying more than needed.

\section{A: Can I get a bag of thinly sliced toast bread please?}


B: Thinly sliced....

A: Yep.

B: They're all thinly sliced, so....

The knowledge about the extent to which interlocutors follow or flout these maxims is important, because it helps in the production and interpretation of spoken and written discourse and to know whether the social goals are being manipulated politely or impolitely between interlocutors.

\title{
3. Impoliteness
}

If politeness is about the use of linguistic strategies to maintain and promote harmonious relations between language users in society, impoliteness nevertheless, is sometimes used by the users of language as linguistic strategies to attack face or to strengthen the threat encoded in an FTA. Culpeper (2001) labels such linguistic strategies as (impoliteness). To illustrate what he means different ways of criticizing a piece of writing by a student are presented:

\author{
Perhaps it could have been improved Politeness \\ It was not good \\ It was bad \\ It was crap
}

You must have shit for brains.

Impoliteness

The above scale goes from being very polite to very impolite. The first utterance can be considered as very polite because of the use of 'hedging' expressed by "perhaps" which would normally reduce the severity of the criticism. Another thing that can be said regarding this utterance is that "It could have been improved" as an indirect way of expressing criticism. The speaker can be said to have flouted Grice's maxim of manner, and have implied criticism rather than having stated it directly. Brown and Levinson (1987) call such use of language as an off-record politeness strategy. Down the scale, the utterance "you must have shit for brains" is seen as an extreme positive impoliteness strategy performed to attack face and damage the social harmony. This interpretation might be arrived at due to the use of the taboo word 'shit' and the personalization of the criticism, expressed linguistically through the use of "you." As for how the utterances in between the very polite and impolite are interpreted, it would depend on the context they are said in. They might be perceived as impolite if it was said by a teacher as a criticism. All in all, the perception of an utterance as polite or impolite depends primarily on the hearer's understanding of what is said by the speaker, whether it is the speaker's intention to attack or support face.

\section{Impoliteness in Drama}

In an answer to the question 'why is impoliteness important for the study of drama?' Culpeper (2005) views impoliteness as a type of social aggression that has been perceived as a source of entertainment for people watching and reading dramatic texts and performances. He claims that impoliteness is typically rare in language and is viewed as outlawed. Normally things that are rare and socially forbidden would be interesting and attractive. As evidence of this we can think of the compulsive desire of children to do what they have been told not to or adults making jokes about sex in their social interactions in conservative societies.

In drama therefore, Culpeper (Ibid) argues that impoliteness is not thrown randomly in dramatic discourse. Wherever there is tension between characters there is development in characterization and plot. In our interpretation of dramatic characterization, our assumptions about (im)polite behaviours would be relatively different from those we make in real life situations. The reasons for such an assumption are; Firstly, when dealing with dramatic characters, normally the readers and audience would assume a complete set of behaviours that would be typical for the construction of a character. Secondly, characters' linguistic behaviours in dramatic discourse are not seen as spontaneous but are normally viewed as motivated choices of the writer/author of the text. However, we can draw some conclusions from fictional texts; because in the construction of a fictitious universe of discourse, there would be many aspects that are based on real life.

As a result of this, we can make some initial judgments about real life from fictional discourse. In such cases we will be able to compare and contrast sets of behaviours or social constructions of images or identities in real life in past and present.

\section{5. (Im)politeness and Characterization in Bab Al-Hara}

Bab Al-Hara (The Neighbourhood Gate) is a five-season Syrian-Arabic drama series. It is directed by Bassam 
Al-Mulla and broadcast on MBC. The five seasons were aired in the months of Ramadan from 2006-2010.

The series depicts real life in the old city of Damascus, where every Hara (neighbourhood) in the city has its own chosen representative (Mukhtar/Ageed). The society is patriarchal, and each village or area chooses a person to represent it before the government. Typically, such a person will hold high status among people because of his age, and wealth. Each Mukhtar will form a council consisting of the elderly, the educated and the powerful men in the neighbourhood to run the everyday business of the neighbourhood. Normally, members of the council vary in their social status, where the wealthy members would support the Mukhtar in giving charity to the poor and maintain the properties in the neighbourhood. Members were generally of the mercantile class, securing steady incomes off their small businesses such as barber shops, bakeries, groceries and other commercial activities.

The fifth season of Bab Al-Hara was aired in the month of Ramadan 2010 and continues the story of resistance against French occupation, which has been the theme since the beginning of the series. The season begins with the announcement that Abu Shehab, Ageed of the neighbourhood, has been killed, and a new Ageed must be appointed. The honour is given to Muataz, Abu Issam's youngest son and the nephew of Abu Shehab, as he is a righteous person who is highly respected in the neighbourhood. He is strong-willed, has good morals, and is highly patriotic. His female counterpart, unusual for the era, plays a significant role this season. Um Joseph is an older woman who has lost her family to the French, and is trying to avenge their deaths by killing off soldiers. In season four she is shot by the French during one of her attempts to kill them. She was taken to hospital and was supposed to go on trial for her crimes, but with the help of the youth of the neighbourhood, she managed to escape and took refuge in one of their houses. The French suspect that they were the ones to help Um Joseph escape, and as punishment issue a decree to destroy the neighbourhood's gate. This is a breach of their security and is seen as a challenge to them. In reaction to this decree, Muataz and a few other men tried to defend their people and shot one of the soldiers. They were forced to flee to al-Ghota, the countryside of Damascus, where rebels against the French occupation were based. Events aggravate further, and a decree is issued by the French-run Damascus Municipality to demolish some houses with the help of an implanted spy (Ma'moon Bek) who is an officer in the French Army. He pretends to be the son of a former Ageed who has not been seen for years. He earns most of the people's trust and reports back to the army the goings-on of the neighbourhood. His true identity is later revealed and is killed in the neighbourhood's main square.

\section{Significance and Objective of the Study}

The significance of this study can be seen in two ways: Firstly, the phenomenon of (im)politeness in language is important and is easily found in daily language, literature, and media discourse. Therefore, it is worthwhile to put in greater effort to study this phenomenon to get a deeper understanding of the nature of human communication.

Secondly, (im)politeness in the context of media discourse, especially in the Arab world, has not received much attention from linguists. Thus, it is hoped that this study will contribute to this field.

The main objective the study aims to achieve is to examine the linguistic behaviour of some characters in the fifth season of the TV series. There are characters endowed with authority in the show, such characters represent the power of the French occupation at that time. One of those characters is Abu Jawdat who is the chief police officer in the neighbourhood. It is the main goal of this study to examine his linguistic behaviour in relation to some minor characters (Abu Satoor and Subhi) and the major character (Muataz) when they are conversing together in instances of interrogation.

In the remainder of this paper, selected exchanges will be split in smaller conversational chunks that will be analyzed by critically reviewing them in light of the Brown and Levinson (1987) politeness model, Culpeper's framework of impoliteness (1996) and Grice's (1975) cooperative principles and its maxims; making use of the social variables of power, social distance and rank of impositions to assess the degree of the FTA. It is hoped that the analysis will help in explaining how these characters might place themselves in relation to one another, and how they manipulate one another in pursuit of their goals.

The selected situations below have been transliterated using a devised chart of Arabic transliteration system (see appendix below). The situations are transliterated in both Arabic and English symbols for the convenience of reading. In order to avoid the issue of inaccurate translation, the present researcher resorted to the literal translation of words that are relevant to encoding polite and impolite messages in the discussed utterances.

\section{Discussion}

In this section Abu Jawdat's (the chief police officer in the neighbourhood) interrogations with other major and minor characters in the show will be analyzed. Abu Jawdat is a minor character who represents the power of the official authorities who are responsible for enforcing the rule of law. Abu Jawdat is also a corrupt cop who takes 
bribes to release prisoners, or not question suspects. One character who bribed him is Al-Nimis who is also a minor character in the show. Al-Nimis lives in the neighbourhood as an assistant to Ma'moon Bek, and plays the role of an underhanded person who manages to buy properties in the neighbourhood for the benefit of Ma'moon Bek. He also creates conflict between people in the neighbourhood. Al-Nimis' character is similar to Abu Jawdat's character in the sense that he also accepts bribes and takes money illegally because he is basically jobless.

\subsection{Situation 1}

In the situation below Abu Jawdat orders Noori (his assistant officer) to arrest Al-Nimis on the grounds of being a suspect, along with Abu Satoor, in killing Abu Hlal. The conversations below show how Abu Jawdat's power entitles him to behave differently with Noori, Abu Satoor and Al-Nimis.

[Situation 1, Bab Al-Hara Season 5, Episode 7]

$$
\begin{aligned}
& \text { د1: النمس: إيهـشو ما في غير هالنمس بالحارة، شيه! شو آعدين بلا شغل بالكركون؟ ما عندك زباين؟ نوري! دئيئة! نوري لوين آخدني؟ } \\
& \text { د2:نوري: عالكركون لوين يعني! } \\
& \text { د3: النمس: عالكركون! فكرت عندك عالبيت! (بدهشة) عالكركون! شباب ما حلوة عشان سمعتي بالحارة! نزلوني و أنا بروح لحالي لكان! }
\end{aligned}
$$

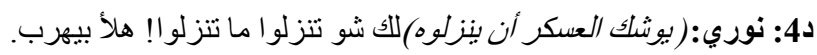

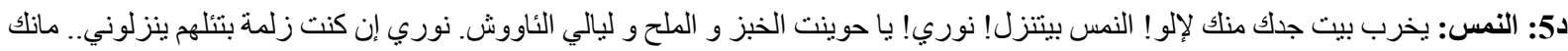

$$
\begin{aligned}
& \text { زلمة شفت! (ثم يوجه كلامه للعسكر) شباب ركيد عالئاووش! (يخاطب نوري مرئ نورة ثانية) الحئني نوري. } \\
& \text { د6: نوري: للك شو ركيد ما ركيد! لوين رايحيين؟ }
\end{aligned}
$$

Turn 1. Al-Nimis: ei shuu ma fii gheir ilNimis bilhara shih! shuu ?aa9diin balaa shughul bilkarakon maa 9indak zabayin! nurii! da?ii?a! la wein ?aakhdnii

Turn 2. Noori: 9alaa ilkaraakoon la wein y9nii !

Turn 3. Al-Nimis: 9alaa ilkarakon fakarit 9indak 9alaa ilbeit !

(Astonished) 9alaa ilkarakon! shabab !maa hilweh 9ashaan sum9tii bilhara

nazluunii w ?ana barooh lahalli.

Turn 4. Noori: (addresses his assistant cops) lak shuu itnazluu maa tnazluu hala? beyhorub!

Turn 5. Al-Nimis: (addresses the cops with Noori) yikhrib beit jidak manak la?ilu ilnimis byitnazal nuri ya hiweinit ilkhubiz w ilmilh w lyaalii il?aawuush

nuri ?in kint zalameh bit?ilhum ynazluunii.....

maank zalameh shift! shabab irkeed 9alaa il?aawuush ilha?nii nuri.

Turn 6. Noori: lak shuu rkeed maa rkeed! lawein raihiin ? ...

The first section of the situation from turn 1-6 shows Al-Nimis' linguistic behaviour in the arrest scene. In turn 1 he uses an off record strategy where he violates the quality maxim by being sarcastic and comparing the police to merchants who seek customers to guarantee their work runs smoothly, and ironically asks Noori 'where are you taking me?' In turn 3 he also uses another off record strategy violating the quality maxim, uttering a contradictory statement in his reply to Noori, where he told him 'I thought you might be taking me to your house as a guest!' This is done to achieve comic effect which is typical of Al-Nimis as he often resorts to banter impoliteness. In turn $5 \mathrm{Al}-\mathrm{Nimis}$ is denied the request of going to the police station on his own to keep his reputation. He attacks the positive face of the officers who are taking him in by ordering them to take him running to the police station. This behaviour with Noori is contrasted with the second section of the scene which begins when Al-Nimis is forced into the prison cell, where he meets with Abu Satoor. At this stage we can see a shift in his linguistic behaviour because of Abu Satoor's vengeful reaction.

$$
\begin{aligned}
& \text { (بِخل النمس زنز انة النظارة) } \\
& \text { د7: النمس:( يكّم النمس أبو ساطور و يلطم على وجهه) أهليين بالغالي! هلا و اللا! حيَّا اله! إيه والل! لعيونك هالرئبة سدادة يا أبوساطور. }
\end{aligned}
$$

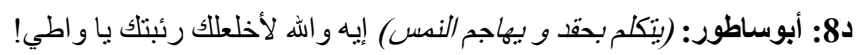

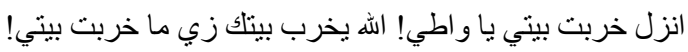

$$
\begin{aligned}
& \text { د9:النمس: (يصرخ مستغيثا) الحئني يا نوري! }
\end{aligned}
$$

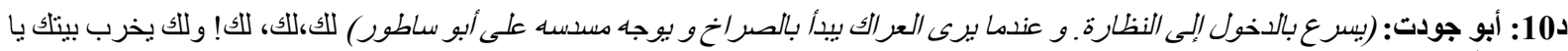

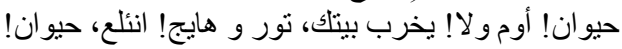




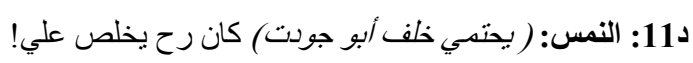

(In the police station, Al-Nimis enters the prison cell)

Turn 7. Al-Nimis: (talking to Abu Satoor)

?ahleen bilghalii hala wallah hayallah ?ei wallah la9yuunak hal ra?abeh sdaadeh ya Abu satoor.

Turn 8. Abu Satoor: (with vengeance)

?ei wallah la?khla9 ra?batak ya watii...? inzil kharbit beitii lak watii ?allah ykhrib beitik zay maa kharabit bitii

Turn 9. Al-Nimis: ( shouting for help) ilha?nii ya nuri

(Abu Jawdat rushes into the cell, seeing the fight he aims his gun at Abu Satoor and starts yelling)

Turn 10. Abu Jawdat: lak lak lak! walaak yikhrib beitak ya haywaan! ?uum wlaa! yikhrib beitak toor w haayij ?in?ili9 haywaan.

Turn 11. Al-Nimis: (hiding behind)Abu Jawdat)Kan rah ykhalis 9alay

In turn 7, Al-Nimis uses an off record politeness strategy violating the quality and quantity maxims, trying to insinuate that Abu Satoor must be sympathetic with him. The situation gets very tense and develops into physical retaliation on Abu Satoor's part. He uses impoliteness baldly on record where he utters the insult- "ya watii" in turn 8 which literally means a low person. Abu Jawdat tries to end the fight using his authority as chief of police. He uses a bald on-record impoliteness strategy where he uses his rank of imposition and social power and orders them to stop fighting. He refers to Abu Satoor with the taboo word "haywaan"; which literally means animal, and the expression "toor w hayij" (raving ox). He also used a negative impoliteness strategy at the end of turn 10 where he gives an order to Abu Satoor "?in?ili9" (get lost) and repeats the taboo words used earlier. This is all done to assert his power as a police officer over him.

$$
\begin{aligned}
& \text { د12: ابو جودت: (بغضب) سد بوزك! (ثم يأمر نوري): نوري! بتعلو فلئة لهالضالالي و بتفهو... إنوو هون بالنظارة في حكومة، و مافي حدا بيعتدى } \\
& \text { على حدا } 12 \\
& \text { 13: ابو ساطور:(بتحدي) بس ياللي بدو يضربني لسه امه ما جابته! }
\end{aligned}
$$

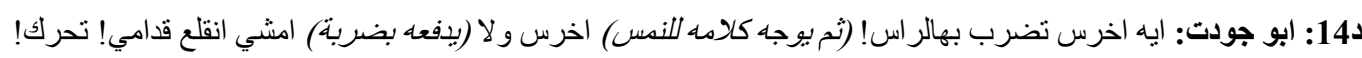

Turn 12. Abu Jawdat: (speaking to Al-Nimis) sid buuzak (Then he orders Noori) nuri bti9milu fal?ah la haldalalii w bitfahmuu ?inu huun bilnazaara fii hukuumeh maa hadaa byi9tidii 9alaa hadaa

Al-Nimis (crying)

Turn 13. Abu Satoor (defiant) bas yalli bidu yidribni lisa ?imu maa khil?itu!

Turn 14. Abu Jawdat: ?ei ikhraas tidrab bihalraas!

\section{( Then he addresses Al Nimis)}

?ikhras wla (hitting him) ?imshii ?in?ili9 ?idaamii! itharak!

In turn $12 \mathrm{Abu}$ Jawdat makes a direct order to Noori to lash Abu Satoor in order to put him in his place and make him understand that there is no one above the law. This is seen as a negative impoliteness strategy. He uses a condescending term (dalali) (bully) which literally means (a person who is gone astray) to attack his positive face, and again asserts his power over him. Abu Satoor in turn 13 is still defiant and goes baldly on record making a direct face threatening act towards both hearers' negative face when he tried to frighten them by a direct statement which literally means "the person who wants to put me to beat me has not been born yet". Something that is strikingly obvious is that because Abu Jawdat holds higher power and is more in control of the conversational floor, he uses a negative impoliteness strategy, scorning Abu Satoor and is condescending to him, ordering him to shut up in turn 14 using the word "?ikhras" and ridicules him when he says "tidrab bihalraas" which is equivalent to "stupid prick" - a positive impoliteness strategy intended to destroy the hearer's face.

$$
\begin{aligned}
& \text { د15: النمس: (بإذعان) شرف سيدي! }
\end{aligned}
$$

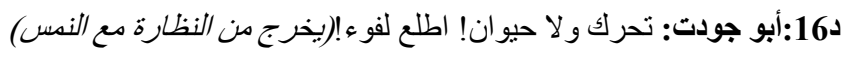

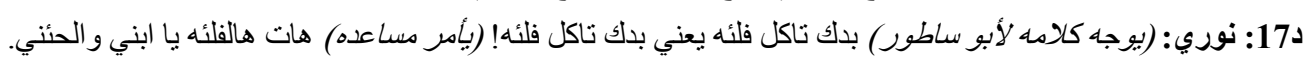

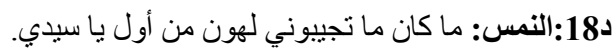

$$
\begin{aligned}
& \text { د19:أبو جودت: وطي صوتلك وللك! } \\
& \text { د20: النمس: ضروري تلحشوني مع هاد الأبوساطور !.. الله لايوفئوكان رح يخنتني.. رووح يا أبوساطور يبعتلك حكة وقلة أضافير.... }
\end{aligned}
$$




$$
\begin{aligned}
& \text { يا سيدي افهموا بئى الدنيا مقامات. لو كان كل مين ما كان متل مين ما كان، كان كل مين ما كان بمكان! لكان! }
\end{aligned}
$$

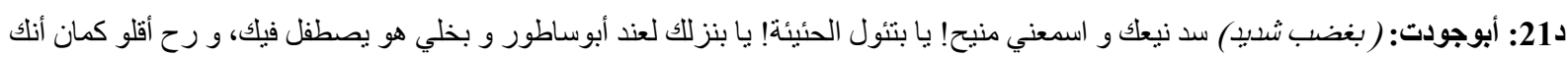

$$
\begin{aligned}
& \text { انت إللي فسدت عليه! } \\
& \text { د222: النمس: إيه حاجتاك بقى ما بتعملها! أنا بعر فك أبو جودت مانك لأئم لهارجة. }
\end{aligned}
$$

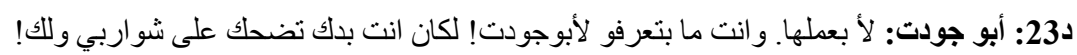

Turn 15. Al Nimis: (humbly) sharrif siidii!

Turn 16. Abu Jawdat: itharak wlaa haywaan! itla9 lafoo? !

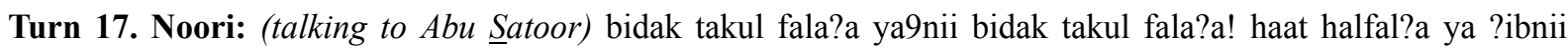
wilha?nii

Turn 18. Al-Nimis: maa kaan maa tjiibuunii lahoon min ?awal yaa siidii.

Turn 19. Abu Jawdat: watii șuutak wlaak!

Turn 20. Al Nimis: darurii tilhashunii ma9 hadaa ila?abuusatoor bilnazaarah! ?allah la ywaf?uu kaan rah ykhni?nii!.. ruuh yaa ?abu satoor yib9atlak hakeh w ?ilit ?dafiir rabii!..

yaa siidii ifhamuu ba?aa ildinyeh ma?aamaat law kaan kil miin maa kaan mitil miin maa kaan. kaan kul miin maa kan bimakaan. lakan!

Turn 21. Abu Jawdat: (Angrily)sid nii9ak w isma9nii mniih $\underline{\text { !.. }}$

Yaa bit?uul ilha?ii?a yaa banazlak la9ind ?abu saatoor w bakhalii huwi yistifil fiik. w rah? ?a?uluu kamaan ?inak intaa ?ilii fasadit 9aliih.

Turn 22. Al Nimis: ei haajtak ba?a maa bti9malhaa ba9rafk?abu jawdat manak la?iim lahadarajih

Turn 23. Abu Jawdat: la? bi9malhaa w inta maa bt9rafu la?abu jawdat ! lakaan inta bidak tidhak 9alaa shwaarbii wlak.....

In the third section of this scene Abu Jawdat assumes almost the same kind of linguistic behaviour with Al-Nimis. In turn 14 he orders Al-Nimis to go to his office but in an impolite way where the order is made baldly on record using the taboo word "?in?ili9 ?idamii" which literally means (get lost and start walking in front of me). In turn 15 Al-Nimis politely acknowledges the order and recognizes the positive face of Abu Jawdat by using his title "sidii"- "sir." This is an acknowledgement of his inferior position and an assertion of Abu Jawdat's power over him. In turn 18 Al-Nimis politely blames Abu Jawdat for putting him together with Abu Satoor by recognizing his positive face and using his title "sir". In turn 21 Abu Jawdat speaks angrily and makes a direct order using profane language "sidbuzak," (shut your mouth) and threatens to return him to Abu Satoor's cell if he does not tell the truth.

The above analysis shows that speakers with more power hold more control over the conversational floor and more right to attack other people's face. Even though Abu Jawdat is seen in the previous scene as a powerful character because of his authority as a police officer, there are other characters in the show who can defy him and cause him to change his interactive role — one of whom is Muataz.

\subsection{Situation 2}

In the next situation we will look at Abu Jawdat's behaviour with Subhi and Muataz in relation to his authority as the police officer in chief of the neighbourhood. Subhi is one of the good young men in the neighbourhood and a minor character in the show. He is arrested by Abu Jawdat on the grounds of being a relative of the suspect Abu Draa9 who killed Abu Shehab, the previous Ageed of the neighbourhood who disappeared after a battle with the French. Even though Subhi is the son of "El Edaashari" a character in the third season who was known as a swindler in the neighbourhood who repented before his death in the same season, Subhi is the opposite of his father. He is renowned for being an honest and hardworking young man, and is even seen as one of the revolutionaries in $\mathrm{Al}$ Ghotah along with Muataz.

In the situation below Muataz is told by his uncle Abu Gassem that Subhi has been arrested by Abu Jawdat's men and he has nothing to do with the murder. Being the Ageed, Muataz goes to ask Abu Jawdat to release Subhi. The manifestation of this request will be seen below.

[Situation 2, Bab Al-Hara Season 5, Episode 8]

$$
\text { د1: أبو جودت: (بتهـيد لصبحي) هلأ انت، بدك تعترف باللتي هي أحسن ولا لا؛! }
$$




$$
\begin{aligned}
& \text { د2: دبحي: بشو بدك اياني أعنرف؟ }
\end{aligned}
$$

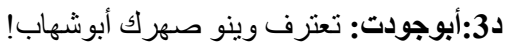

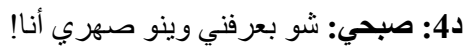

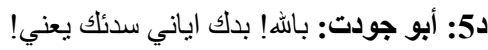

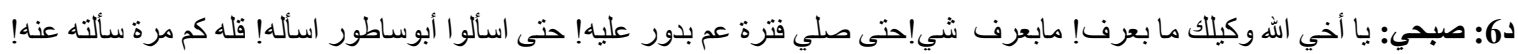

$$
\begin{aligned}
& \text { د77: أبو جودت: (بتهايد) صبحي! إن طلعت وإن نزلت بدك تعترف وينها }
\end{aligned}
$$

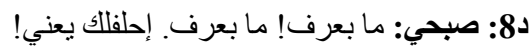

$$
\begin{aligned}
& \text { د9: أبوجودت: لأ! كله إلا تحلف. بالأخص إنت! إلك أب الله برحمه! (ثم يأمر نوري) }
\end{aligned}
$$

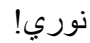

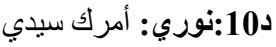

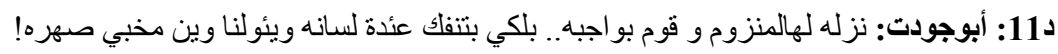

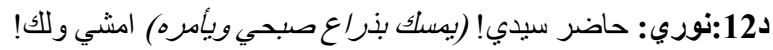

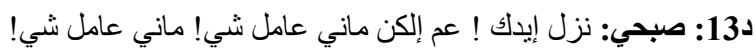

$$
\begin{aligned}
& \text { د14: نوري: عم ائلك امشي معي أحسلك! }
\end{aligned}
$$

Turn 1. Abu Jawdat: (interrogating Subhi) hala? intaa bidak ti9tirif bilatii hiya ?ahsan wala la? ?

Turn 2. Subhi: bshuu bidak yaanii ?a9tirif?

Turn 3. Abu Jawdat: ti9tirif weinuu sihrak ?abu draa9!

Turn 4. Subhi :shuu bi9arifnii weinuu sihrii ?ana!

Turn 5. Abu Jawdat: ballah ! bidak yanii sad?ak ya9nii !

Turn 6. Subhi: yaa ?akhii ?allah wakiilak maa ba9rif! maa ba9rif shii! hataa sarlii fatraa 9am badawer 9aliih ! hataa isa?luu ?abu satoor is?aluh! ?uluh kam maraa sa?ltuh 9anu.

Turn 7. Abu Jawdat: subhii ! ?in tli9it w ?in nzilit bidak ti9tirif weiynuh !

Turn 8. Subhi: maa ba9rif! maa ba9rif ?ihliflak ya9nii.

Turn 9. Abu Jawdat: la? Kilu ?ilaa tihlif bil?khas ?intih ! ?ilak ?ab ?allah yirhnamuh .

(Ordering Noori) nuurii

Turn 10. Noori: (Entering):?amrak siidii

Turn 11. Abu Jawdat: nazluh lahalmanzoom w ?uum bwaajbuh. balkii bitinfak 9i?idit lsaanuh w bi?uulilnaa wein mkhabii sihru

Turn 12. Noori: haader sidii ! imshii wlaak!

Turn 13. Subhi: nazil ?iidak! 9am ?ilkun manii 9aamil shii , manii 9aaml shii

Turn 14. Noori: (angrily) 9am ?ilak ?imshii ma9ii ?hssalak!

The situation has two sections. The first begins with Abu Jawdat interrogating Subhi. He asks him a rhetorical question directly on record, which is to be perceived as a face threatening act in turn 1 . The content of the question is related to revealing the place where his brother in law, Abu Draa9, the suspect in the killing of Abu Shehab is hiding. Subhi acknowledges the authority of Abu Jawdat in turn 2 by responding to him with another rhetorical question "bshuu bidak yaanii ?a9tirif ?" which literally means (what do you want me to confess?). However, Subhi in turn 4 denies knowledge of where his in-law is hiding by responding with an exclamatory sentence which means (how I would know where my in law is!). In turn 5 Abu Jawdat uses a positive impoliteness strategy where he speaks condescendingly, enforcing his power over the conversational floor. In turn 6 Subhi uses the form of address "ya ?akhii" in order to claim reciprocity with Abu Jawdat; to deny any knowledge about his in-law. Abu Jawdat, being sceptical, performs a negative impoliteness strategy in turn 7, frightening Subhi by threatening him if he does not tell where Abu Draa9 is, detrimental action will be taken against him. He also speaks condescendingly of him and scorns his father in turn 9 which is a positive impoliteness strategy. He says, (la? Kiluh ?ilaa tihlif bil?khas ?inta ! ?ilak ?ab ?allah yirhamuh.) which literally means (No! Don't put yourself under oath! Especially you! You had a father. May Allah have mercy over his soul! He is known for it). At the end of the turn Abu Jawdat orders Noori to return Subhi to his cell and beat him. 


$$
\begin{aligned}
& \text { د15: معتز: (يفتح الباب بقوة بدون استأذان، و يأمر نوري) نوري إتركه! (ثم بوجه كلاده لأبو جودت) }
\end{aligned}
$$

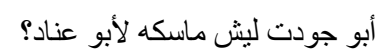

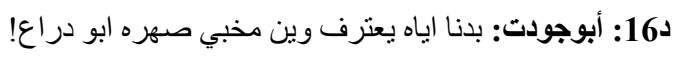

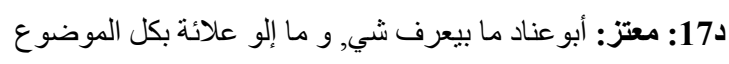

$$
\begin{aligned}
& \text { د18: أبو جودت: (يحاول ان بيحدى معتز من خلال سلطته كرجل أمن بمثل القانون) اسمع سيد معتز! انت ما دخللك بنوب! و هيك انت عم بتعطل }
\end{aligned}
$$

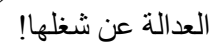

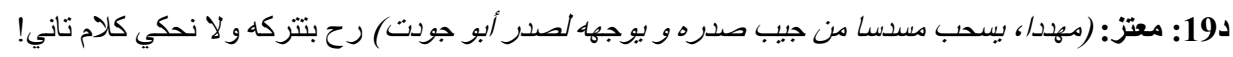

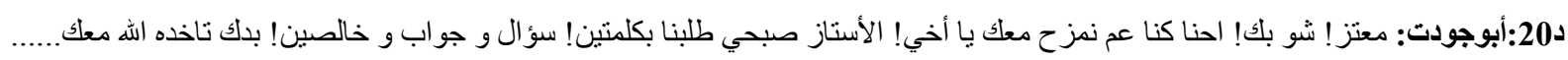

Turn 15. Muataz: (He rushes into Abu Jawdat's office opening the door violently and ordering Noori) nuri ?itriku

(Then he addresses Abu Jawdat challengingly) ?abu Jawdat! leish maaskuh la?abu 9naad?

Turn 16. Abu Jawdat: bidna iyaah yi9tirif wein mkhabii sihruh ?abu draa9.

Turn 17. Muataz: ?abu 9naad maa bi9raf shii w maaloo 9alaa?a bikil ilmawduu9.

Turn 18. Abu Jawdat: (trying to defy Mu'ataz with his power as a police officer)

ismaa9 sayid mu9taz ?inta maa dakhalak bnuub! w heik ?inta 9am bit9atil il9adaaleh 9an shighilhaa!

(threating)

Turn 19. Muataz: (pulling out his gun and pointing it into Abu Jawdat's chest) rah btitrikuh wila bahkii kalaam taanii

Turn 20. Abu Jawdat: mua9taz ! shu baak ? nihnnaa kina 9am nimzah ma9aak ya a?khii ! il?istaaz s subhii talabnaa bkilimtein! su?aal w jawaab w khaalsein ! bidak taakhduh, ?allah ma9aak....

The level of discourse changes in the situation with the entrance of Muataz. In turn 15, he shows superiority of power over Abu Jawdat. He speaks badly on-record to Noori, ordering him to let Subhi go free, then addresses Abu Jawdat challengingly which is a positive impoliteness strategy of snubbing the hearer and failing to acknowledge his power. A shift in the conversational roles is seen due to the fact that Muataz holds more social power because he speaks as a rebellious Ageed, and the police officer answers questions in an act of interrogation. Muataz snubs him by calling him informally with his nick name (Abu Jawdat), fails to acknowledge his official status, and asks him why he is holding Subhi (Abu 9naad). In turn 16 Abu Jawdat answers the question directly, obeying the cooperative principle maxim which is an implicit acknowledgement of Muataz's superior power and evidence that he holds control of the conversational floor. Muataz confirms what Subhi said earlier to Abu Jawdat that he has nothing to do with the murder and no knowledge of Abu Draa9's place. This is seen as a further snubbing of the officer's authority which is a positive impoliteness strategy from Muataz's end. Abu Jawdat tries to defy Muataz using his authority as an officer of the law, yet he addresses Muataz with a formal title "sayid" which means sir. This is again a recognition of Muataz's power over him. The delay in releasing Subhi forces Muataz to perform a negative impoliteness strategy accompanied with a non-verbal behaviour to increase the level of the threat. In turn 19 Muataz threatens Abu Jawdat with a gun to his chest. He wants Subhi to be released immediately. The response that Abu Jawdat gives in turn 20 is evidence of his submission to Muataz's power. He performs an off record politeness strategy where he violates the maxim of quantity, saying more than needed and flouts the maxim of quality, telling him, "kina 9am nimzah ma9ak" which literally means (we were kidding with you). His use of the polite term of address when speaking about Subhi using "il?istaaz" (mister) is also a further evidence of his recognition of Muataz's power over him.

\section{Conclusion}

The change in the interactive role of the behaviour of Abu Jawdat in the above two situations has been explained in light of (Im)politeness theories. It has been revealed that the social variable, power, is important in projecting the social image of characters in the show. This is shown in the superiority of Abu Jawdat's linguistic behaviour with Al-Nimis and Abu Satoor. He was in control of the conversational floor-because of his social power that comes from his authority as a police officer-as opposed to his inferiority in front of the rebellious Muataz - the Ageed of the neighbourhood and the rebel against the French-who has more chances of attacking and damaging Abu Jawdat's face. This in turn shows us how social images are reflected in society.

The impolite linguistic behaviour of Abu Jawdat towards Abu Satoor and Al-Nimis on the one hand and the impolite linguistic behaviour of Muataz towards Abu Jawdat — to suit his character as a rebel—on the other hand 
reinforces Culpeper's claim that impoliteness is not thrown randomly into the text. On the contrary, it is systematically built to complicate the events in the story and create suspense. It also shows how characters place themselves in relation to one another. Abu Jawdat places himself as a police officer in relation to Abu Satoor and Al-Nimis, thus his impoliteness towards them is understandable. The image that is opposite to this is presented with Muataz who is the chosen Ageed and a rebel of Al-Ghouta, which means he is a freedom fighter against the French and their regime which is represented by Abu Jawdat. Thus Muataz's impoliteness towards Abu Jawdat is justified and is perceived positively by the audience.

In addition, our judgements as the audience about these characters are very much governed by the set of linguistic behaviour connected with each character. For example, Abu Jawdat is seen as a corrupt cop who abuses his power to gain money from lesser characters in the show. He uses impoliteness- that is perceived negatively by the audience- towards minor characters, while Muataz's impolite linguistic behaviour with Abu Jawdat is seen as payback against Abu Jawdat's negative social image. We tend to sympathize with Muataz as he uses impolite speech acts to rebel against an oppressor.

Finally, the presented analysis above is by no means exhaustive and final. It merely presents a small attempt by the researcher to account for Arabic media discourse in the field of Arabic drama using pragmalinguistic tools to show that such tools can provide different perspectives of looking at Arabic media discourse. More research needs to be conducted in this field to validate the conclusion of this paper.

\section{References}

Abdesslem, H. (2001). Politeness Strategies in the Discourse of Drama: A Case Study. Journal of Literary Semantics, 30(2), 111-138. http://dx.doi.org/10.1515/jlse.2001.001

Austin, J. L. (1962). How to Do Things with Words. Oxford: Oxford University Press.

Brown, P., \& Levinson, S. (1978). Universals in Language Usage: Politeness Phenomena. In E. N. Goody (Ed.), Questions and Politeness: Strategies in Social Interaction (pp. 56-289). Cambridge: Cambridge University Press.

Brown, P., \& Levinson, S. (1987). Politeness: Some Universals in Language Usage. Cambridge: Cambridge University Press.

Brown, R., \& Gilman, A. (1989). Politeness Theory and Shakespeare's Four Major Tragedies. Language in Society, 18, 159-212. http://dx.doi.org/10.1017/S0047404500013464

Carter, R., \& Burton, D. (Eds.). (1982). Literary Text and Language Study. London: Edward Arnold.

Carter, R. (Ed.). (1982). Language and Literature: An Introductory Reader in Stylistics. London/Boston: G. Allen \& Unwin.

Carter, R., \& Simpson, P. (Eds.). (1989). Language, Discourse, and Literature: An Introductory Reader in Discourse Stylistics. London/Boston: Unwin Hyman. http://dx.doi.org/10.4324/9780203396711

Crystal, D. (2003). A Dictionary of Linguistics and Phonetics. Oxford: Blackwell.

Culpeper, J. (1996). Towards an Anatomy of Impoliteness. Journal of Pragmatics, 25(3), 349-367. http://dx.doi.org/10.1016/0378-2166(95)00014-3

Culpeper, J. (2001). Language and Characterisation: People in Plays and Other Texts. Harlow: Longman.

Culpeper, J., Bousfield, D., \& Wichmann, A. (2003). Impoliteness Revisited: With Special Reference to Dynamic and Prosodic Aspects. Journal of Pragmatics, 35(10-11), 1545-1579. http://dx.doi.org/10.1016/S0378-2166(02)00118-2

Culpeper, J. (2005). Impoliteness and Entertainment in the Television Quiz Show: The Weakest Link. Journal of Politeness Research, 1(3), 5-72.

Culpeper, J. (2009). Reflections on a Cognitive Stylistic Approach to Characterisation. In J. Vandaele, \& G. Brône (Eds.), Cognitive Poetics: Goals, gains, and gaps. Applications of Cognitive Linguistics Series (pp. 125-159). Berlin: Mouton de Gruyter,

Culpeper, J. (2011). Impoliteness: Using Language to Cause Offence. Cambridge: University Press. http://dx.doi.org/10.1017/CBO9780511975752

Davies, E. (1987). A Contrastive Approach to the Analysis of Politeness Formulas. Applied Linguistics, 8(1), 75-88. http://dx.doi.org/10.1093/applin/8.1.75

Fowler, R. (1981). Literature as Social Discourse: The Practice of Linguistic Criticism. London: Batsford 
Academic and Educational.

Goffman, E. (1967). Interaction Ritual-Essays on Face-to-Face Behavior. New York: Pantheon Books.

Goffman, E. (1971). Relations in Public: Microstructure of the Public Order. Hannondsworth: Penguin.

Goffman, E. (1972). On Face-Work: An Analysis of Ritual Elements in Social Interaction. In J. Laver, \& S. Hutcheson (Eds.), Communication in Face-to-Face Interaction (pp. 319-346). Hannondsworth: Penguin.

Gregoriou, C. (2009). English Literary Stylistics. Basingstoke: Palgrave Macmillan.

Grice, H. P. (1989). Studies in the May of Words. Massachusetts: Harvard University Press.

Holmes, J. (1995). Women, Men and Politeness. London: Longman.

Lakoff, R. (1973). The Logic of Politeness; or, Minding Your P's and Q's. In C. Corum, T. C. Smith-Stark, \& A. Weiser (Eds.), Papers from the Ninth Regional Meeting of the Chicago Linguistic Society (pp. 292-305). Chicago, Illinois: Chicago Linguistic Society.

Lakoff, R. (1975). Language and Woman's Place. New York: Harper and Row.

Lakoff, R. (1989). The Limits of Politeness: Therapeutic and Courtroom Discourse. Multilingua, 8(2-3), 101-129. http://dx.doi.org/10.1515/mult.1989.8.2-3.101

Lakoff, R. (1990). Talking Power: The Politics of Language in Our Lives. Glasgow: Harper Collins.

Leech, G. (1969). A Linguistic Guide to English Poetry. London: Longman. http://dx.doi.org/10.1049/el:19690536

Leech, G. (1980). Explorations in Semantics and Pragmatics. Amsterdam: Benjamins.

Leech, G. (1981). Style in Fiction: A Linguistic Introduction to English Fictional Prose. London/New York: Longman.

Leech, G. (1983). Principles of Pragmatics. London: Longman.

Levinson, S. C. (1983). Pragmatics. Cambridge: Cambridge University Press.

Locher, M. A. (2004). Power and Politeness in Action: Disagreements in Oral Communication. Berlin/New York: Mouton de Gruyter. http://dx.doi.org/10.1515/9783110926552

Locher, M. A., \& Watts, R. J. (2005). Politeness Theory and Relational Work. Journal of Politeness Research, 1, 9-33.

Mills, S. (2003a). Gender and Politeness. Cambridge: Cambridge University Press. http://dx.doi.org/10.1017/CBO9780511615238

Mills, S. (2005). Gender and Impoliteness. Journal of Politeness Research, 1, 263-280.

Mills, S. (2002). Rethinking Politeness, Impoliteness and Gender Identity. In L. Litosseliti, \& J. Sunderland (Eds.), Gender Identity and Discourse Analysis. Amsterdam: John Benjamins.

Mulla, B. (Director \& Producer). (2010). Bab Al-Hara 5 [Television series, episodes 7, 8]. Bubai. Middle East Broadcasting Center Group.

Nammari, D. (2007, October 12). Syrian Soap Opera Captivates Arab World. The Washington Post. Retrieved from http://www.washingtonpost.com/wp- dyn/content/article/2007/10/12/AR2007101200238.html

Rym, G., \& Zaatari, M. (2007, October 15). Eid mixes solemn duties with simple fun as faithful mark end of Ramadan. Daily Star, Lebanon. Retrieved from http://www.dailystar.com.lb/News/Local-News/Oct/15/Eid-mixes-solemn-duties-with-simple-fun-as-faithfu 1-mark-end-of-Ramadan.ashx\#axzz2eReiw1zF

Searle, J. R. (1976). The Classification of Illocutionary Acts. Language in Society, 5, 1-24. http://dx.doi.org/10.1017/S0047404500006837

Searle, J. R. (1979). Expression and Meaning. Cambridge: Cambridge University Press. http://dx.doi.org/10.1017/CBO9780511609213

Semino, E., \& Culpeper, J. (Eds.). (2002). Cognitive Stylistics: Language and Cognition in Text Analysis. John Benjamins: Amsterdam.

Sharyan, A. (2000). Politeness Strategies in American and Arabic Fiction: A Thematic-Pragmatic Study of John Steinbeck and Najuib Mahfouz (Doctoral dissertation). Babasaheb Ambedkar Marathwada University, India. 
Sharyan, A. (2003). Najuib Mahfouz's The Thief and the Dogs: A Pragmalinguistic Analysis. Journal of Humanities and Social Sciences. Sanaa University, Yemen.

Short, M. (1989). Discourse Analysis and the Analysis of Drama. In R. Carter, \& P. Simpson (Eds.), Language, Discourse and Literature: An Introductory Reader in Discourse Stylistics (pp. 139-168). London: Hyman.

Short, M. (Ed.). (1988). Reading, Analysing, and Teaching Literature. London/New York: Longman.

Short, M. (1990). Discourse Analysis in Stylistics and Literature Instruction. Annual Review of Applied Linguistics, 11, 181-195. http://dx.doi.org/10.1017/S0267190500002038

Simpson, P. (1989). Politeness Phenomena in Ionesco's The Lesson. In R. Carter, \& P. Simpson (Eds.), Language, Discourse and Literature: An Introductory Reader in Discourse Stylistics (pp. 139-168). London: Hyman.

Spencer-Oatey, H. (2000). Rapport Management: A Framework for Analysis. In Culturally Speaking, Managing Rapport through Talk across Cultures (pp. 11-46). London: Continuum.

Spencer-Oatey, H., \& Jiang, W. (2003). Explaining Cross-Cultural Pragmatic Findings: Moving from Politeness Maxims to Sociopragmatic Interactional Principles (SIPs). Journal of Pragmatics, 35(10-11), 1633-1650. http://dx.doi.org/10.1016/S0378-2166(03)00025-0

Spencer-Oatey, H. (2005). (Im)Politeness, Face and Perceptions of Rapport: Unpacking their Bases and Interrelationships. Journal of Politeness Research, 1, 95-119.

Toolan, M. J. (1998). Language in Literature: An Introduction to Stylistics. London: Arnold. http://dx.doi.org/10.1177/096394709800700106

Turner, K. (1996). The Principal Principles of Pragmatic Inference: Politeness. Language Teaching, 2, 1-13. http://dx.doi.org/10.1017/S0261444800008211

Watts, R. J. (1989). Relevance and Relational Work: Linguistic Politeness as Politic Behaviour. Multilingua, 8(2-3), 131-166. http://dx.doi.org/10.1515/mult.1989.8.2-3.131

Watts, R. J. (2003). Politeness. Cambridge: Cambridge University Press. http://dx.doi.org/10.1017/CBO9780511615184

Watts, R. J. (2005). Linguistic Politeness and Politic Behaviour: Reconsidering Claims for CP Universality. In R. J. Watts, S. Ide, \& K. Ehlich (Eds.), Politeness in Language: Studies in its History, Theory and Practice (pp. 43-69). Berlin: Mouton de Gruyter. http://dx.doi.org/10.1515/9783110199819.1.43

Watts, R. J., Ide, S., \& Ehlich, K. (2005a). Introduction. In R. J. Watts, S. Ide, \& K. Ehlich (Eds.), Politeness in Language: Studies in its History, Theory and Practice (pp. 1-17). Berlin: Mouton de Gruyter. http://dx.doi.org/10.1515/9783110199819.0.1

Watts, R. J., Ide, S., \& Ehlich, K. (Eds.). (2005b). Politeness in Language: Studies in its History, Theory and Practice (2nd ed.). Berlin: Mouton de Gruyter. http://dx.doi.org/10.1515/9783110199819

\section{Appendix}

Transliteration System for Arabic Language Symbols of Consonants

\begin{tabular}{|c|c|c|}
\hline Arabic Symbols & Specifications & $\begin{array}{l}\text { Roman } \\
\text { Symbols }\end{array}$ \\
\hline أ & Voiceless glottal stop & $?$ \\
\hline ب & Voiced bilabial stop & $\mathrm{b}$ \\
\hline ت & Voiceless alveolar stop & $\mathrm{t}$ \\
\hline$\dot{H}$ & Voiceless interdental fricative & th \\
\hline ج & Voiced alveopalatal affricate & $\mathrm{j}$ \\
\hline$\tau$ & Voiceless pharyngeal fricative & $\underline{\mathrm{h}}$ \\
\hline$\dot{\tau}$ & Voiceless uvular fricative & $\mathrm{kh}$ \\
\hline 2 & Voiced alveolar stop & $\mathrm{d}$ \\
\hline$\dot{j}$ & Voiced interdental fricative & th \\
\hline J & Voiced alveolar flap & $\mathrm{r}$ \\
\hline j & Voiced alveolar fricative & $\mathrm{z}$ \\
\hline س & Voiceless alveolar fricative & $\mathrm{s}$ \\
\hline ش & Voiceless alveopalatal fricative & $\mathrm{sh}$ \\
\hline
\end{tabular}




\begin{tabular}{|c|c|c|}
\hline ص & Voiceless alveolar emphatic fricative & $\underline{\mathrm{s}}$ \\
\hline ض ض & Voiced alveolar emphatic stop & $\mathrm{d}$ \\
\hline b & Voiceless alveolar emphatic stop & $\underline{\mathrm{t}}$ \\
\hline ל & Voiced interdental emphatic fricative & $\underline{\underline{z}}$ \\
\hline$\varepsilon$ & Voiced pharyngeal fricative & 9 \\
\hline$\dot{\varepsilon}$ & Voiced uvular fricative & $\mathrm{gh}$ \\
\hline ف & Voiceless labio-dental fricative & $\mathrm{f}$ \\
\hline ق & Voiceless uvular stop & $\mathrm{q}$ \\
\hline ك5 & Voiceless velar stop & $\mathrm{k}$ \\
\hline J & Voiced alveolar lateral & 1 \\
\hline 5 & Voiced bilabial nasal & $\mathrm{m}$ \\
\hline ن & Voiced alveolar nasal & $\mathrm{n}$ \\
\hline 。 & Voiceless glottal fricative & $\mathrm{h}$ \\
\hline
\end{tabular}

\section{Symbols of Vowels}

\begin{tabular}{|c|c|c|c|}
\hline & $\begin{array}{l}\text { Arabic } \\
\text { Symbols }\end{array}$ & Specifications & $\begin{array}{l}\text { Roman } \\
\text { Symbols }\end{array}$ \\
\hline $\begin{array}{l}\text { Short } \\
\text { Vowels }\end{array}$ & $\begin{array}{l}\text { Fatha } \\
\text { Dama } \\
\text { Kasra } \\
\text { أو }\end{array}$ & $\begin{array}{l}\begin{array}{l}\text { Front half-opened } \\
\text { unrounded }\end{array} \\
\text { Back close rounded } \\
\text { Front open spread } \\
\text { as in doktoor (دكتور) in } \\
\text { Arabic and "orphan" in } \\
\text { English }\end{array}$ & $\begin{array}{l}\mathrm{a} \\
\mathrm{u} \\
\mathrm{I} \\
\mathrm{o}\end{array}$ \\
\hline Long Vowels & أو & $\begin{array}{l}\text { Front open unrounded } \\
\text { Back close rounded } \\
\text { Front close unrounded }\end{array}$ & $\begin{array}{l}\text { aa } \\
\text { uu } \\
\text { ii }\end{array}$ \\
\hline Semi-Vowels & و & $\begin{array}{l}\text { Non-syllabic Palatal } \\
\text { Approximant } \\
\text { Non-Syllabic } \\
\text { Labio-Velar } \\
\text { approximant }\end{array}$ & $\begin{array}{l}\mathrm{y} \\
\mathrm{w}\end{array}$ \\
\hline Diphthong & إيه & $\begin{array}{l}\text { as in leih (ليه) in Arabic } \\
\text { and "tail" in English }\end{array}$ & ei \\
\hline
\end{tabular}

\section{Copyrights}

Copyright for this article is retained by the author(s), with first publication rights granted to the journal.

This is an open-access article distributed under the terms and conditions of the Creative Commons Attribution license (http://creativecommons.org/licenses/by/3.0/). 